\title{
Estrogen-Induced $\mu$-0pioid Receptor Internalization in the Medial Preoptic Nucleus Is Mediated via Neuropeptide Y-Y Receptor Activation in the Arcuate Nucleus of Female Rats
}

\author{
Richard H. Mills, Richard K. Sohn, and Paul E Micevych \\ Department of Neurobiology, David Geffen School of Medicine, Laboratory of Neuroendocrinology, Brain Research Institute, University of California, Los \\ Angeles, California 90095
}

\begin{abstract}
The endogenous peptides $\beta$-endorphin ( $\beta$-END) and neuropeptide Y (NPY) have been implicated in regulating sexual receptivity. Both $\beta$-END and NPY systems are activated by estrogen and inhibit female sexual receptivity. The initial estrogen-induced sexual nonreceptivity is correlated with the activation and internalization of $\mu$-opioid receptors (MORs), in the medial preoptic nucleus (MPN). Progesterone reverses the estrogen-induced activation/internalization of MOR and induces the sexual receptive behavior lordosis. To determine whether NPY and endogenous opioids interact, we tested the hypothesis that estrogen-induced MOR activation is mediated through $N P Y-Y_{1}$ receptor $\left(Y_{1} R\right)$ activation. Retrograde tract tracing demonstrated $Y_{1} R$ on $\beta$-END neurons that projected to the MPN. Sex steroid modulation of MOR in the MPN acts through NPY and the $Y_{1} R$. Estradiol administration or intracerebroventricular injection of NPY activated/internalized $\mathrm{Y}_{1} \mathrm{R}$ in the arcuate nucleus and MOR in the MPN of ovariectomized (OVX) rats. Moreover, the selective $\mathrm{Y}_{1} \mathrm{R}$ agonist [Leu31, Pro34]-Neuropeptide Y (LPNY) internalized MOR in the MPN of OVX rats. The $\mathrm{Y}_{1} \mathrm{R}$ antagonist (Cys ${ }^{31}$, Nva ${ }^{34}$ )-Neuropeptide $\mathrm{Y}$ $(27-36)_{2}$ prevented estrogen-induced $\mathrm{Y}_{1} \mathrm{R}$ and MOR activation/internalization. NPY reversed the progesterone blockade of estradiolinduced $\mathrm{Y}_{1} \mathrm{R}$ and MOR internalization in the arcuate nucleus and MPN, respectively. Behaviorally, LPNY inhibited estrogen plus progesterone-induced lordosis, and the MOR-selective antagonist D-Phe-Cys-Tyr-d-Trp-Orn-Thr-Pen-Thr amide reversed LPNYinduced inhibition of lordosis. These results suggest that a sequential sex steroid activation of NPY and MOR circuits regulates sexual receptivity.
\end{abstract}

Key words: internalization; reproduction; hypothalamus; receptors; lordosis; estrogen; progesterone

\section{Introduction}

Two neuropeptides, neuropeptide Y (NPY) and $\beta$-endorphin $(\beta$ END), have been implicated in the transduction of steroidal information into the CNS and modulate reproductive function. Estrogen receptors have been colocalized in $\beta$-END and NPY immunoreactive neurons (Morrell et al., 1985; Sar et al., 1990), and estradiol regulates the expression of both NPY and $\beta$-END in the arcuate nucleus of the hypothalamus (ARH) (Petraglia et al., 1982; Wardlaw et al., 1982; Wilcox and Roberts, 1985; Baskin et al., 1995; Priest and Roberts, 2000).

$\beta$-END-containing neurons are concentrated in the ARH (Finley et al., 1981; Micevych and Elde, 1982; Khachaturian et al., 1983), which project throughout the neuroaxis including the medial preoptic nucleus (MPN) (Cheung and Hammer, 1995). Cen-

\footnotetext{
Received May 6, 2003; revised Nov. 10, 2003; accepted Nov. 25, 2003.

This work was supported by National Institutes of Health Grants HD 39495, HD 07228, and DA13185. We thank Jan Asai and Wendy Yang for technical assistance, Dr. Kevin Sinchak for insightful comments on this manuscript, and Donna Crandall for assistance with the artwork.

Correspondence should be addressed to Dr. Paul E Micevych, Department of Neurobiology, David Geffen School of Medicine, University of California, Los Angeles, CA 90095-1763. E-mail: pmicevych@mednet.ucla.edu.

R. H. Mills' present address: Department of Obstetrics and Gynecology, Uniformed Services University of the Health Sciences, 4301 Jones Bridge Road, Bethesda, MD 20814. E-mail: rmills@usuhs.mil.

DOI:10.1523/JNEUROSCI.1366-03.2004

Copyright $\odot 2004$ Society for Neuroscience $\quad$ 0270-6474/04/240947-09\$15.00/0
}

tral injections of either NPY or $\beta$-END inhibit reproductive behavior in rats and hamsters when primed with estradiol and progesterone (Sirinathsinghji et al., 1983; Wiesner and Moss, 1984; Clark et al., 1985; Gorzalka et al., 1997; Torii et al., 1999; Corp et al., 2001). Furthermore, infusion of $\beta$-END into the MPN inhibited lordosis (Sirinathsinghji, 1986), suggesting that $\beta$-END is an endogenous ligand of the $\mu$-opioid receptor (MOR) in this nucleus.

The MOR, a G-protein-coupled receptor, undergoes agonistinduced receptor internalization (von Zastrow et al., 1993). Internalization can be used as an assay for activation of hypothalamic MOR (Eckersell et al., 1998; Sinchak and Micevych, 2001, 2003 ) and has been correlated with an inhibition of lordosis after estradiol treatment, microinjections, exogenous [D-Ala(2),NMe-Phe(4),Gly(5)-ol]-enkephalin or endogenous MOR agonists, and endomorphin-1 (Eckersell et al., 1998; Sinchak and Micevych, 2001). Progesterone reversal of estradiol-induced MOR activation/internalization is correlated with a facilitation of lordosis (Sinchak and Micevych, 2001). Opioid receptor antagonism blocks estrogen-induced internalization; the proposed mechanism is that estrogen regulates the release of MOR-active endogenous peptides, one of which is $\beta$-END.

Central injections of NPY inhibit sexual receptivity and proceptivity in steroid-primed rodents. The first report of NPY in 
rats used a supraphysiological dose of estradiol benzoate (EB; 100 $\mu \mathrm{g}$ ) to induce lordosis (Clark et al., 1985), but a subsequent study repeated their findings with a more physiological relevant dose of EB $(5 \mu \mathrm{g})$, albeit in Syrian hamsters (Corp et al., 2001). Despite these results, the NPY receptor subtype mediating behavioral actions has not been elucidated; the NPY- $Y_{1}$ subtype $\left(\mathrm{Y}_{1} \mathrm{R}\right)$ is responsible for NPY-induced luteinizing hormone (LH) release (Kalra et al., 1992; Besecke et al., 1994; Leupen et al., 1997). This suggested that $\mathrm{Y}_{1} \mathrm{R}$ might be involved in reproduction. Additional evidence for this was the distribution of $Y_{1} R$ in the $A R H$ (Migita et al., 2001) and its regulation by sex steroids. Hypothalamic $\mathrm{Y}_{1} \mathrm{R}$ mRNA levels are elevated on the afternoon of proestrus (but see Parker et al., 1996; Jain et al., 1999; Xu et al., 2000), indicating that $\mathrm{Y}_{1} \mathrm{R}$ expression is regulated by sex steroids.

We hypothesized that the site of NPY action on endogenous opioid peptides may be the ARH, which is enriched in $\mathrm{Y}_{1} \mathrm{R}$ immunoreactive cells and NPY and is the origin of $\beta$-END cell bodies that project and innervate the MPN. Moreover, in males, NPY immunoreactive fibers have been reported in close apposition to $\beta$-END immunoreactive neurons (Fuxe et al., 1997, 1998), which express the $\mathrm{Y}_{1} \mathrm{R}$ subtype (Broberger et al., 1997; Pickel et al., 1998). These results suggest that NPY may activate $\mathrm{Y}_{1} \mathrm{R}$ on $\beta$-END neurons, which in turn produce the initial inhibition of sexual receptivity after estradiol treatment of ovariectomized (OVX) rats.

The present study used behavioral analysis, immunocytochemistry, and retrograde tract tracing to determine whether the estradiol and progesterone regulation of reproductive behaviors was mediated by the activation of $\mathrm{Y}_{1} \mathrm{R}$ in the $\mathrm{ARH}$ and activation of MORs in the MPN. These results have been presented in preliminary form (Mills et al., 2001).

\section{Materials and Methods}

Animal treatments. Adult female Long-Evans rats (200-255 gm; Charles River, Wilmington, MA) were OVX by the supplier and allowed to survive 2 weeks before experimentation. At the University of California, Los Angeles (UCLA), all animals were maintained in Plexiglas cages under controlled light $\left(12 \mathrm{hr}\right.$ light/dark cycle) and temperature $\left(22-24^{\circ} \mathrm{C}\right)$ with ad libitum access to food and water. All of the procedures were approved by the Chancellor's Animal Research Committee at UCLA.

Two weeks after being OVX, all animals were anesthetized with isoflourane (2-3\% 1:1 oxygen) and placed in a stereotaxic frame, and a trephine was performed to implant a guide cannula (Plastics One, Roanoke, VA) into the third ventricle (3V). The coordinates used were anteroposterior, bregma $(-0.8 \mathrm{~mm})$, lateral (on the midline, above the superior longitudinal sinus), and dosoventral $(-6.5 \mathrm{~mm})$, and were defined by Swanson (1998). Beginning 3-5 d after surgery, rats were given a subcutaneous injection of EB (50 or $2 \mu \mathrm{g}$ ) or vehicle (Safflower oil), followed $30 \mathrm{hr}$ later with an intracerebroventricular injection of vehicle [artificial CSF (aCSF); $n=8$ per group], NPY $(0.5 \mathrm{nmol} ; n=6$ per group; Bachem, Torrance, $\mathrm{CA}$ ), $\mathrm{Y}_{1} \mathrm{R}$ antagonist $\left(\mathrm{Cys}^{31}{ }^{31} \mathrm{Nva}^{34}\right)$-Neuropeptide $\mathrm{Y}$ $(27-36)_{2}\left(\mathrm{CNNY}_{27-36} ; 10 \mathrm{nmol} ; n=6\right.$ per group; Bachem, King of Prussia, PA), or a selective $\mathrm{Y}_{1} \mathrm{R}$ agonist, [Leu31, Pro34]-Neuropeptide $\mathrm{Y}$ (LPNY; $10 \mathrm{nmol}$; Bachem) through a 29 gauge inner cannula connected to a $25 \mu \mathrm{l}$ Hamilton syringe via a plastic tube. The inner cannula extended $1 \mathrm{~mm}$ beyond the tip of the guide cannula. The duration of the injections was $1 \mathrm{~min}$. To allow for diffusion, the inner cannula was left in place for an additional minute after microinjection. Thirty minutes after intracerebroventricular injection of drugs, rats were anesthetized deeply with sodium pentobarbital $(100 \mathrm{mg} / \mathrm{kg})$ and perfused transcardially with physiologic saline $\left(4^{\circ} \mathrm{C}\right)$, followed by $4 \%$ paraformaldehyde in $0.1 \mathrm{M}$ Sörensen's phosphate buffer $(\mathrm{PB})\left(4^{\circ} \mathrm{C}\right)$. Brains were removed, postfixed for 4-24 hr in the paraformaldehyde solution, and then transferred to $15 \%$ sucrose in $0.1 \mathrm{M} \mathrm{PB}, \mathrm{pH} 7.5$, for cryoprotection.

To assess the level of receptor internalization after steroid treatment and to determine the interactions between steroids and NPY, animals were given injections of $2 \mu \mathrm{g}$ of EB. Beginning $26 \mathrm{hr}$ after EB injection, all animals were given $500 \mu \mathrm{g}$ of progesterone. Four hours later, rats were given microinjections of vehicle (aCSF; $n=6)$ or NPY $(10 \mathrm{nmol} ; n=8)$ into the $3 \mathrm{~V}$, anesthetized, perfused, and processed for $\mathrm{Y}_{1} \mathrm{R}$ and $\mathrm{MOR}$ immunocytochemistry.

Female receptive behavior. To determine whether activation of $\mathrm{Y}_{1} \mathrm{R}$ in the ARH influences MOR in the MPN that ultimately modulates lordosis, OVX rats with a $3 \mathrm{~V}$ guide cannula were given injections of $2 \mu \mathrm{g}$ of EB and, $26 \mathrm{hr}$ later, $500 \mu \mathrm{g}$ of progesterone. At $30 \mathrm{hr}$ after estrogen injection, rats received either a $3 \mathrm{~V}$ microinjection of aCSF vehicle, NPY $(0.5 \mathrm{nmol})$, a selective $Y_{1} R$ agonist, LPNY (10 nmol; Bachem), or a combination of aCSF vehicle $(n=6)$ or D-Phe-Cys-Tyr-d-Trp-Orn-Thr-Pen-Thr amide (CTOP; $50 \mathrm{nmol} / 2 \mu \mathrm{l} ; n=6$; Bachem), followed 10 min later with an infusion of the selective $\mathrm{Y}_{1} \mathrm{R}$ agonist LPNY (10 nmol) through a 29 gauge cannula.

Animals were tested for receptive (lordosis) behavior with a stimulus male at 15, 30, and $45 \mathrm{~min}$ after microinjection. A lordosis quotient (LQ; the percentage of lordotic postures the female displays $\times 100$ ) was determined. The individual scoring lordosis was blind to the treatment of the animal. The LQ was analyzed using repeated measures ANOVA to assess main effects of time and treatment including any interaction (SigmaStat, version 2.11; Jandel Scientific, San Rafael, CA). If a significant main effect was obtained, post hoc comparisons were conducted using Student-Newman-Keuls test. $p<0.05$ was considered significant.

Retrograde tract tracing experiments. OVX rats were implanted with a guide cannula aimed at the MPN. The coordinates used were anteroposterior, bregma $(+0.1 \mathrm{~mm})$, lateral $(-0.8)$, and dosoventral $(-6.1 \mathrm{~mm})$ and were defined by Swanson (1998). A 29 gauge cannula containing the retrograde tracer FluoroGold (FG; 2\% w/v; Fluorochrome, Denver, CO) extended $1 \mathrm{~mm}$ beyond the tip of the guide cannula into the MPN. One to $2 \mu \mathrm{l}$ of FG was slowly ejected over 10 min from the cannula connected to a $25 \mu$ l Hamilton syringe via a plastic tube. The cannula was allowed to remain in place for an additional $10 \mathrm{~min}$, and the animal was allowed to survive for $10-12 \mathrm{~d}(n=6)$.

Immunocytochemisty. The distribution of $\mathrm{Y}_{1} \mathrm{R}$ immunoreactivity was determined using a rabbit primary antibody raised against aa 356-382 of the rat $Y_{1} R$ (DiaSorin, Stillwater, MN). Free-floating tissue sections were incubated in 4\% NGS (Jackson ImmunoResearch Laboratories, West Cove, PA) in PBS for 60 min, followed by incubation with $\mathrm{Y}_{1} \mathrm{R}$ antibody ( $1: 750$ diluted in $1 \%$ NGS and PBS) at $4^{\circ} \mathrm{C}$ for $18-48 \mathrm{hr}$. The sections were washed, incubated in blocking buffer (Tyramide Signal Amplification kit; NEN Life Science Products, Boston, MA) for $30 \mathrm{~min}$, and then incubated in biotin-conjugated goat anti-rabbit IgG (1:200; Vector Laboratories, Burlingame, CA) for $1 \mathrm{hr}$. Tissue sections were washed in $0.1 \mathrm{M}$ TBS, pH 7.5, incubated in streptavidin-HRP (1:100; NEN Life Science Products) for $30 \mathrm{~min}$, washed in TBS with Tween 20 (Sigma, St. Louis, $\mathrm{MO}$ ), incubated for $5 \mathrm{~min}$ in Flouroscein-conjugated tyramide (1:50; Tyramide Signal Amplification kit; NEN Life Science Products), and then washed in $0.1 \mathrm{M}$ Tris buffer without saline, $\mathrm{pH} 7.5$, and mounted on Superfrost Plus slides (Fisher Scientific, Pittsburgh, PA). Mounted sections were air-dried and coverslipped using Vectashield mounting medium (Vector Laboratories).

The MOR antibody was raised in rabbits against a synthetic fragment (LENLEAETAPLP) corresponding to the intracellular C terminus of rat MOR (MOR ${ }_{387-398}$; a gift from C. Evans and B. Anton, UCLA, Los Angeles, CA). Free-floating tissue sections were washed in PBS and then incubated in $1 \%$ NGS, $1 \%$ BSA, and $0.5 \%$ Triton X-100 in PBS for 60 min. Tissue sections were incubated for $48-72 \mathrm{hr}$ at $4^{\circ} \mathrm{C}$ with the affinitypurified MOR antibody (1:5000) diluted in PBS with $1 \%$ NGS and $0.17 \%$ Triton X-100. The sections were washed, incubated with a goat antirabbit secondary antibody, and processed as described previously.

$\beta$-END was localized with rabbit primary antibodies generated against a synthetic ovine $\beta$-END bound to keyhole limpet hemocyanin (ICN Biomedicals, Costa Mesa, CA). Immunocytochemistry and localization of $\beta$-END was performed by incubating the tissue in PBS with $0.3 \%$ Triton X-100, 20\% NGS, and $\beta$-END antiserum $(1: 10,000)$ at $4^{\circ} \mathrm{C}$ for $18-48 \mathrm{hr}$. After the $\beta$-END antiserum, tissue was washed, incubated with a goat anti-rabbit antibody, and processed as described above. Tetramethylrhodamine-conjugated tyramide (1:50; Tyramide Signal 
Amplification kit; NEN Life Science Products) was used for visualization of the antibody antigen sites of interest.

To establish $\mathrm{Y}_{1} \mathrm{R}$ and $\beta$-END immunoreactive colocalization in the $\mathrm{ARH}$, free-floating tissue sections were processed for $\beta$-END immunocytochemistry, washed in TBS, and avidin/biotin-binding sites were blocked by incubating sections in avidin D (1:100 in TBS) for 15 min, followed by biotin (1:100 in TBS) for $15 \mathrm{~min}$ (Vector Laboratories). Tissue sections were then processed for $\mathrm{Y}_{1} \mathrm{R}$ immunocytochemistry.

Tissue sections from each treatment were grouped and processed in parallel to avoid procedural artifacts and to ensure consistency. Immunocytochemical controls included the omission of primary and secondary antisera and preabsorption of antibodies with appropriate peptide epitopes. Omission of primary antibodies and preabsorption with appropriate epitopes blocked all staining. For the double-label studies, the pattern of staining was compared with the pattern in singly labeled sections, the order of primary antibodies was reversed, and heterologous absorption controls (e.g., the $\mathrm{Y}_{1} \mathrm{R}$ antiserum was absorbed with $\beta$-END peptide) were done. The pattern of staining for each antibody was the same. Neither heterologous preabsorption of primary antibodies nor the order of primary antibodies affected the staining.

Image analysis. All immunocytochemical-labeled sections were analyzed with a Zeiss Axioskop 2 equipped with epiflouresecent illumination, Axiocam CCD camera, and digital image analysis system (Zeiss USA, Thornwood, NY). To identify internalization, tissue sections were examined with a LSM 410 laser-scanning confocal microscope system (Zeiss USA) to visualize the subcellular distribution of $Y_{1} R, \beta$-END, and MOR immunoreactivity. The excitation source was a krypton-argon laser (Coherent, Santa Clara, CA) with output at 488, 568, and $633 \mathrm{~nm}$. Fluorescein was imaged with a $488 \mathrm{~nm}$ emission filter and a $515-540 \mathrm{~nm}$ bandpass filter. Rhodamine was imaged with a $530 \mathrm{~nm}$ emission filter and $560-610 \mathrm{~nm}$ bandpass filter. Images were adjusted for brightness and contrast using the LSM-PC (Zeiss USA) and Adobe PhotoShop (version 6.0) programs before printing with an Epson 1200 color printer.

$\mathrm{Y}_{1} \mathrm{R}$ and MOR immunoreactivity were considered internalized when the majority of immunoreactivity was observed as puncta within the cytoplasm of neuronal cell bodies and processes (Mantyh et al., 1995; Eckersell et al., 1998; Sinchak and Micevych, 2001). An increased level of internalization was correlated with an increased number of immunoreactive structures (Dournaud et al., 1998; Eckersell et al., 1998; Sinchak and Micevych, 2001, 2003). Therefore, to obtain an estimate of the relative internalization, the area of $Y_{1} R$ immunoreactivity in the ARH and MOR immunoreactivity in the dorsal aspect of the medial part of the MPN in every fourth or fifth section was estimated using the KS-300 imaging software (version 3.0; Zeiss USA). Briefly, at a magnification of $225 \times$, threshold brightness was established that discriminated specific from nonspecific staining. This calibration was determined for each measured section. The percentage of area occupied by specific staining (i.e., staining above the threshold) was determined and compared between the treatment groups. Statistical analysis was done separately for $\mathrm{Y}_{1} \mathrm{R}$ immunoreactivity in the ARH and MOR immunoreactivity in the MPN. Treatment groups were compared using a one-way ANOVA. When a significant main effect was obtained, differences were analyzed further using a Student-Newman-Keuls post hoc test (SigmaStat, version 2.11; Jandel Scientific).

Quantitative measurements of $\mathrm{Y}_{1} \mathrm{R} / \beta$-END and $\mathrm{Y}_{1} \mathrm{R} / \beta$-END/FG coexistence were performed by counting the number of ARH cell bodies immunoreactive for $\beta$-END and $\mathrm{Y}_{1} \mathrm{R}$ alone and doubly labeled with $\beta$-END and $\mathrm{Y}_{1} \mathrm{R}$ immunoreactivity. To determine the population of ARH neurons projecting to the MPN, FG, FG/Y ${ }_{1} R, F G / \beta$-END immunoreactivity and $\mathrm{FG} / \mathrm{Y}_{1} \mathrm{R} / \beta$-END immunoreactivity were counted along the rostrocaudal axis of the ARH. To prevent double counting of cells, new counts were adjusted using the Abercrombie correction (Abercrombie, 1946). The total numbers of single-labeled, double-labeled, or triplelabeled cells were averaged across animals.
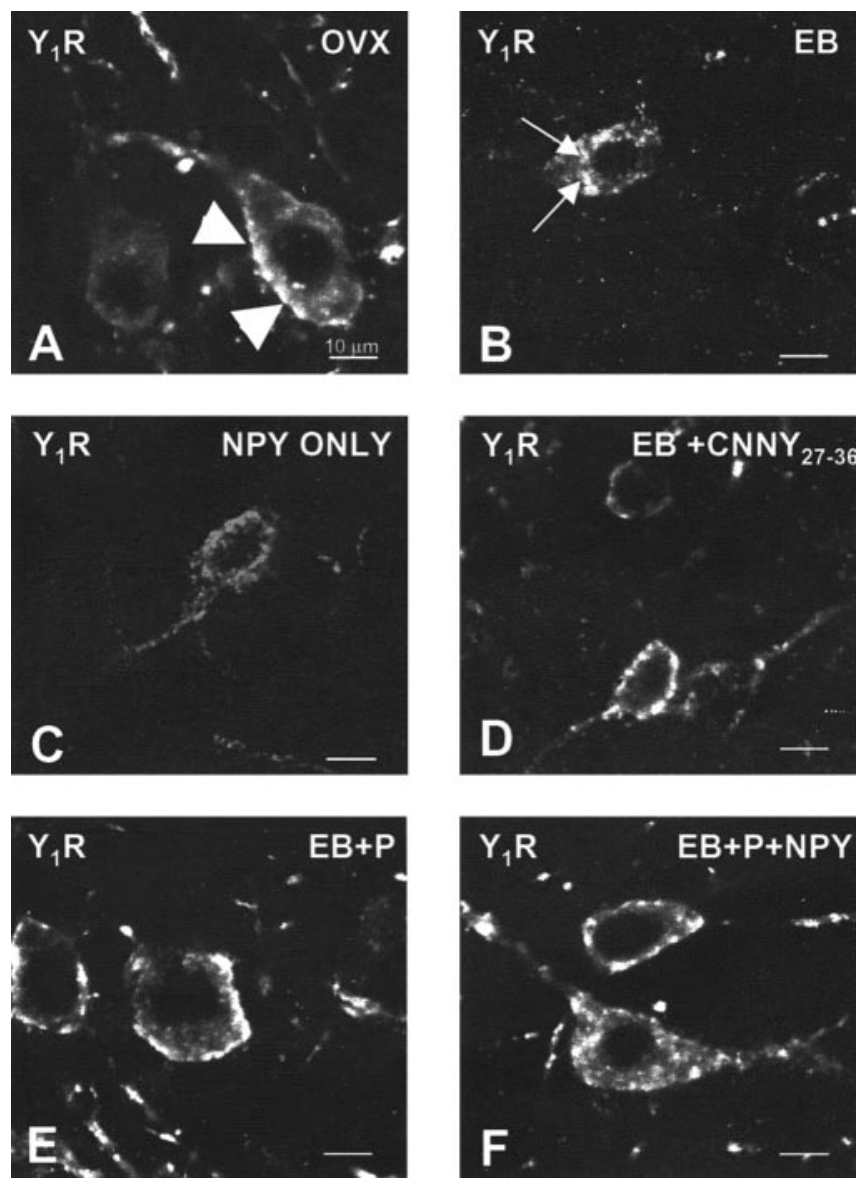

Figure 1. Confocal projections of $Y_{1} R$ neurons in the ARH of $\operatorname{OVX}(A), E B(B), \operatorname{NPY}(C)$, $\mathrm{CNNY}_{27-36}(D)$, EB plus progesterone $(E B+P ; E)$, or $E B+P+N P Y-$ treated $(F)$ rats. Large arrowheads indicate $Y_{1} R$ immunoreactivity associated with the plasma membrane $(A, D, E)$, suggesting that these receptors have not been activated. Small arrows indicate the immunoreactivity was not associated with the plasma membrane, suggesting an internalization of $Y_{1} R(B, C, F)$. Please note that $\mathrm{OVX}$ females showed $\mathrm{Y}_{1} R$ immunoreactivity associated with the membrane and in the cytoplasm.

\section{Results}

Experiment 1: Do treatments that induce $Y_{1} R$ internalization also internalize MOR?

Within the mediobasal hypothalamus, the distribution of $Y_{1} R$ is most pronounced along the third ventricle, in the periventricular nucleus, and in the ARH (data not shown). We observed the greatest number of $\mathrm{Y}_{1} \mathrm{R}$ immunoreactive cells in the $\mathrm{ARH}$, as reported previously (data not shown) (Mikkelsen and Larsen, 1992; Migita et al., 2001). Medial and lateral parts of the ARH contained $\mathrm{Y}_{1} \mathrm{R}$ immunoreactivity that was distributed in a ventral band beneath the ventromedial nucleus (see below). $\mathrm{Y}_{1} \mathrm{R}$ immunoreactivity decorated cell bodies and processes of ARH neurons. $\beta$-END immunoreactive staining was generally present in the cytoplasm of large ARH neurons (see below).

In the $\mathrm{ARH}$ of OVX rats, $\mathrm{Y}_{1} \mathrm{R}$ antibodies outlined neuronal cell bodies and processes, suggesting that the $\mathrm{Y}_{1} \mathrm{R}$ is associated with the plasma membrane (Fig. $1 A$ ). Some cytoplasmic puncta were also observed in $\mathrm{Y}_{1} \mathrm{R}$ immunoreactive cells, suggesting that a portion of $Y_{1} R$ were internalized in the estrogen-free condition. Treatment with either 50 or $2 \mu \mathrm{g}$ of EB produced a similar reorganization of $Y_{1} R$ immunoreactivity. The majority of the immunoreactivity was observed as cytoplasmic punta, whereas the membrane-associated localization of $\mathrm{Y}_{1} \mathrm{R}$ immunoreactivity was 


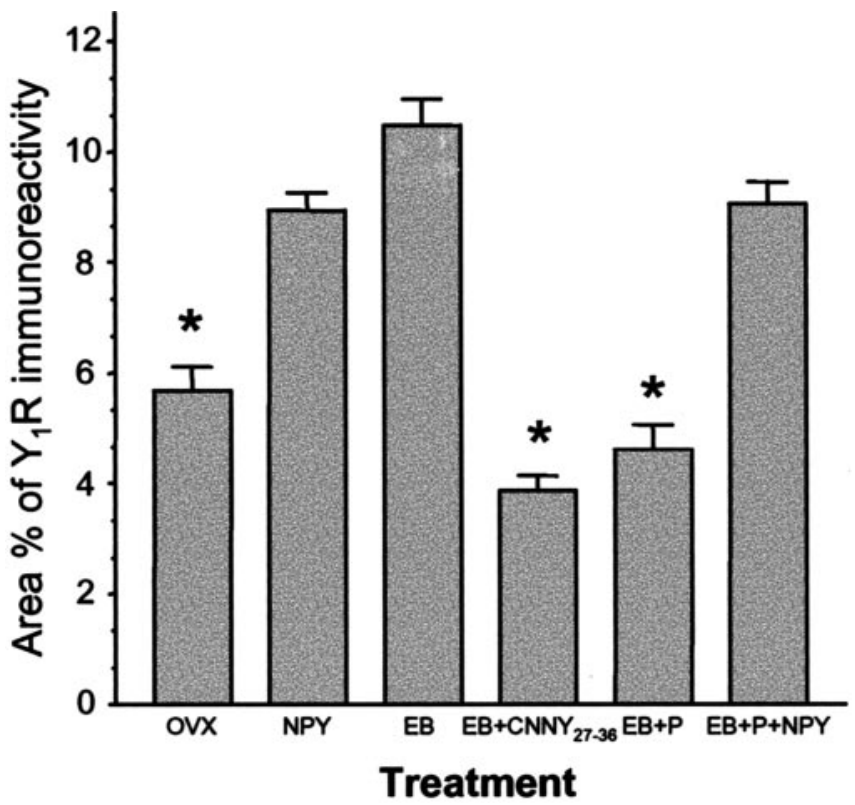

Figure 2. Percentage area of $Y_{1} R$ in the $A R H$ of $O V X$ rats treated with vehicle (OVX), NPY, EB, $E B$ plus $Y_{1} R$ antagonist $\left(E B+C N N Y_{27-36}\right)$, $E B$ plus progesterone $(E B+P)$, or $E B+P+N P Y$. Values presented are means $\pm \mathrm{SEM} .{ }^{*} p<0.05$ versus $\mathrm{NPY}, \mathrm{EB}$, and $\mathrm{EB}+\mathrm{P}+\mathrm{NPY}$.

reduced substantially (Fig. $1 \mathrm{~B}$ ). A significantly greater amount of $\mathrm{Y}_{1} \mathrm{R}$ immunoreactive cell bodies and processes was associated with an internalized pattern of staining in EB-treated females compared with OVX animals (Fig. 2 ). Within the MPN, $\beta$-END immunoreactive fibers were distributed in the periventricular preoptic area and the medial MPN (Cheung and Hammer, 1995), overlapping the distribution of MOR immunoreactivity (Micevych et al., 1997; Eckersell et al., 1998; Sinchak and Micevych, 2001). In the MPN of OVX rats, MOR immunoreactivity was associated with the plasma membrane (Fig. 3A). Steroid treatments altered the subcellular distribution of MOR immunoreactivity and the amount of $\beta$-END immunoreactivity but not the tissue distribution. As we reported previously, EBinduced MOR internalization was also observed in the MPN (Fig. 3B) (Eckersell et al., 1998; Sinchak and Micevych, 2001). Similarly, there was a significant increase of MOR immunoreactivity in EB-treated females compared with OVX animals (Fig. 4).

Infusion of NPY $(0.5 \mathrm{nmol})$ into the $3 \mathrm{~V}$ of OVX rats induced internalization of $\mathrm{Y}_{1}$ Rs in the ARH (Fig. 1C) and MORs in the MPN (Fig. 3C). The infusion of NPY also corresponded to increased $Y_{1} R$ and MOR immunoreactive cell bodies and processes compared with the OVX group (Figs. 2 and 4). This internalization was similar to that seen after treatment with EB (Figs. 2 and 4 ), suggesting that activation of $Y_{1} R$ in the $A R H$ may be related to EB- or NPY-induced MOR internalization. Indeed, LPNY ( ${ }_{1} \mathrm{R}$ specific agonist) infused into the $3 \mathrm{~V}$ of OVX females induced internalization of MORs in the MPN (Fig. $3 G$ ). $\mathrm{Y}_{1} \mathrm{R}$ immunoreactivity was not internalized in $\mathrm{CNNY}_{27-36}$ ( $\mathrm{Y}_{1} \mathrm{R}$ antagonist)treated rats given EB (Fig. $1 D$ ). Similar to the $\mathrm{Y}_{1} \mathrm{R}$ result, $\mathrm{CNNY}_{27-36}$ also blocked MOR internalization in the MPN (Fig. $3 D)$. There was no significant change in MPN MOR immunoreactivity and $\mathrm{ARH} \mathrm{Y}_{1} \mathrm{R}$ fiber density between $\mathrm{CNNY}_{27-36}$ and $\mathrm{OVX}$ animals but a significant decrease in MPN MOR immunoreactivity and $\mathrm{Y}_{1} \mathrm{R}$ fiber density between $\mathrm{EB}$ plus $\mathrm{CNNY}_{27-36^{-}}$ treated animals, and EB treatment was observed $(p<0.05)$ (Figs. 2 and 4 ).
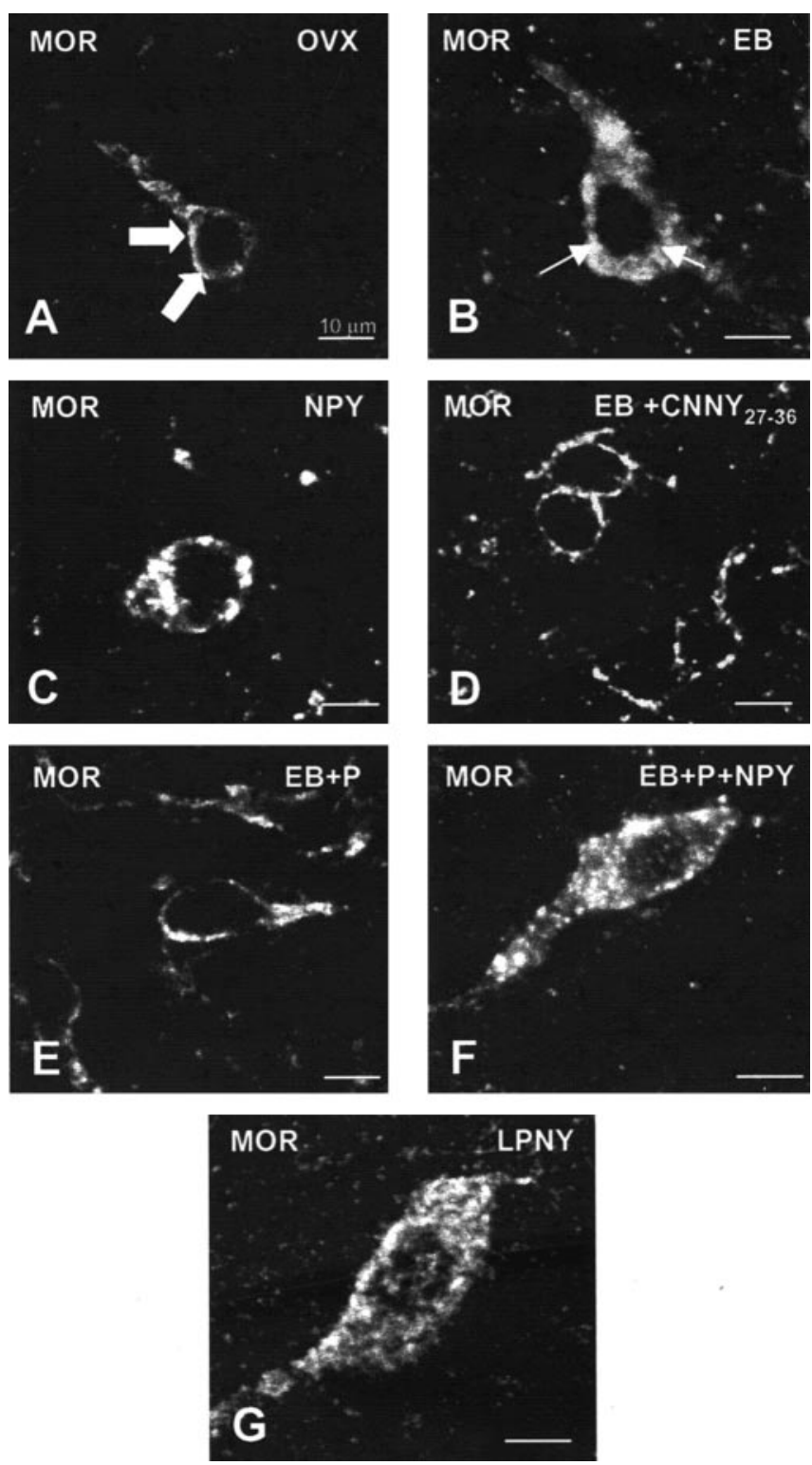

Figure 3. Confocal projections of MOR immunoreactive neurons and processes in the MPN of OVX $(A), \mathrm{NPY}(B), \mathrm{EB}(C), \mathrm{CNNY}_{27-36}(D), \mathrm{EB}$ plus progesterone $(\mathrm{EB}+\mathrm{P} ; E), \mathrm{EB}+\mathrm{P}+\mathrm{NPY}-$ treated $(F)$ rats or LPNY. Large arrowheads indicate MOR immunoreactivity associated with the plasma membrane $(A, D, E)$, suggesting that these receptors have not been activated. Small arrows indicate that immunoreactivity was not associated with the plasma membrane, suggesting an internalization of the $\operatorname{MOR}(B, C, F, G)$.

Experiment 2: Is progesterone blockade of EB-induced MOR internalization mediated through the $Y_{1} R$ ?

As described above, EB induced $\mathrm{Y}_{1} \mathrm{R}$ and MOR internalization, however, $\mathrm{Y}_{1} \mathrm{R}$ immunoreactivity in the ARH and MOR immunoreactivity in the MPN were associated with the plasma membrane and not internalized in EB plus progesterone-treated OVX rats (Figs. $1 E, 3 E$ ). The progesterone blockade of MOR internalization was superceded by the $3 \mathrm{~V}$ infusion of NPY, which internalized $\mathrm{Y}_{1} \mathrm{R}$ in the $\mathrm{ARH}$ and MOR in the MPN (Figs. $1 F, 3 F$ ). Quantified, the internalization was significantly increased in $Y_{1} R$ and MOR labeling compared with vehicle treatment $(p<0.05)$ (Figs. 2 and 4). 


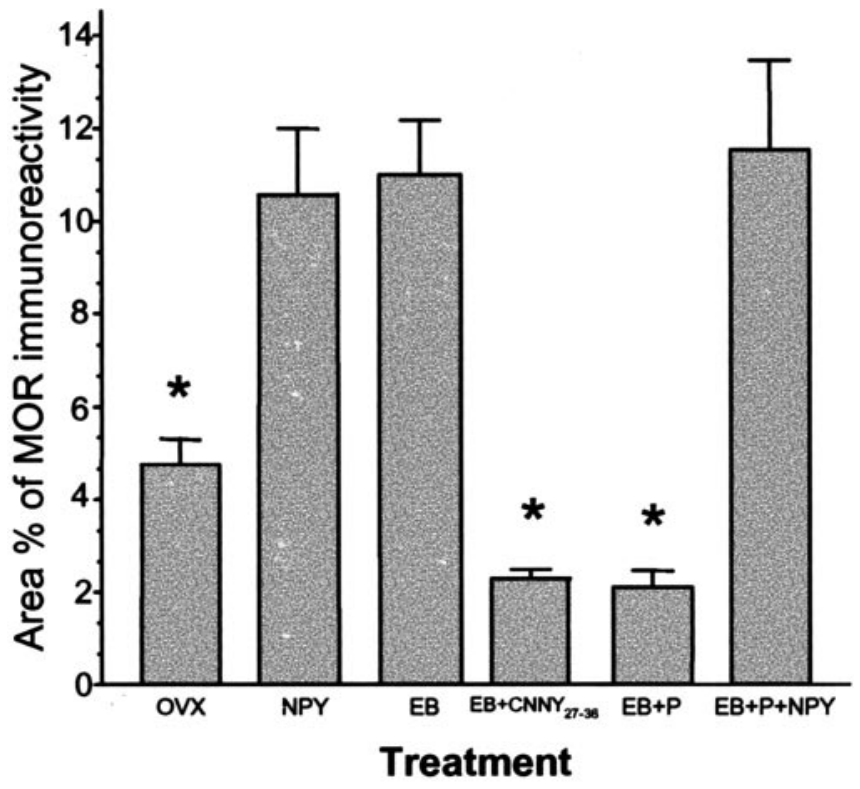

Figure 4. Area percentage of neuropeptide MOR immunoreactivity in the MPN was measured in female rats treated with vehicle (OVX), NPY, EB, EB plus $Y_{1}$ Rantagonist ( $E B+\mathrm{CNNY}_{27-36}$ ), $\mathrm{EB}$ plus progesterone $(E B+P)$, or $E B+P+N P Y$. Values presented are means $\pm S E M .{ }^{*} p<0.05$ versus $N P Y, E B$, and $E B+P+N P Y$.
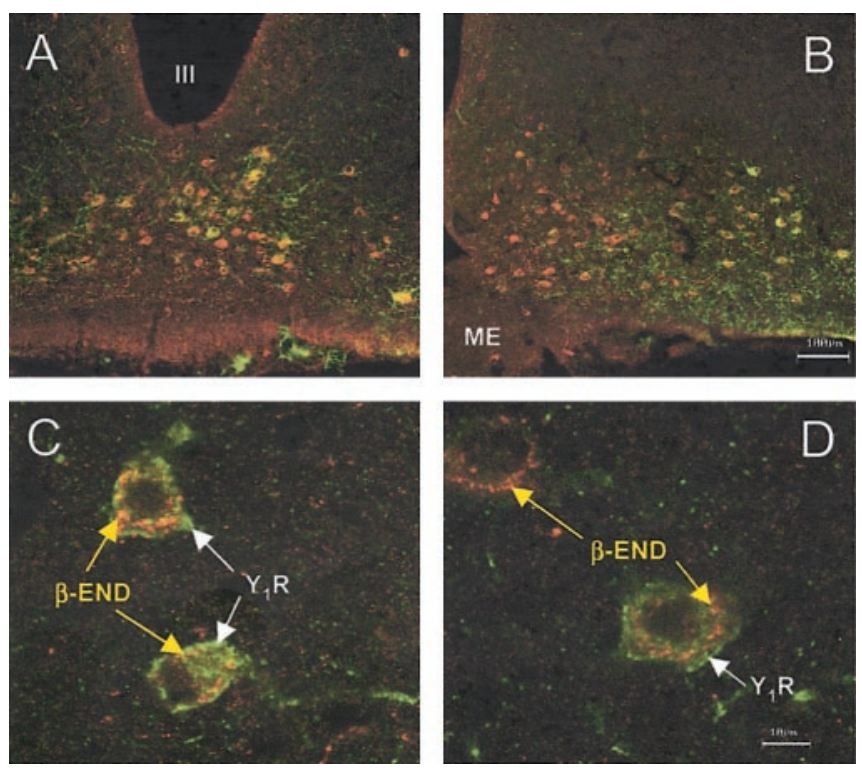

Figure 5. Confocal projections of $\beta$-END and $Y_{1} R$ immunoreactivity in the ARH and doubly labeled neurons of estrogen-primed female rats. $A, B$, Low-power magnification of the distribution of $Y_{1} R$ neurons labeled with FITC (green) and $\beta$-END somata labeled with tetramethylrhodamine (TRITC; red). $\beta$-END immunoreactivity decorated structures within the cytoplasm. The $Y_{1} R$ immunoreactivity was associated with the plasma membrane. Although most $Y_{1} R$ immunoreactive neurons were $\beta$-END immunoreactive, only a subpopulation of $\beta$-END immunoreactive neurons was $Y_{1} R$ immunoreactive (43\%). C, D, Higher-power magnification of doubly labeled $Y_{1} R / \beta$-END and $\beta$-END neurons in the ARH. Note that the $Y_{1} R$ immunoreactivity is associated with the plasma membrane, whereas the $\beta$-END immunoreactivity labels punctuate structures in the cell bodies.

Experiment 3: Do $\beta$-END immunoreactive neurons have $Y_{1} R$ immunoreactivity?

The distribution of $\mathrm{Y}_{1} \mathrm{R}$ and $\beta$-END cell bodies overlapped in the ARH (Fig. 5). To determine whether $Y_{1} R$ and $\beta$-END cell bodies were colocalized, sections containing the ARH were stained with

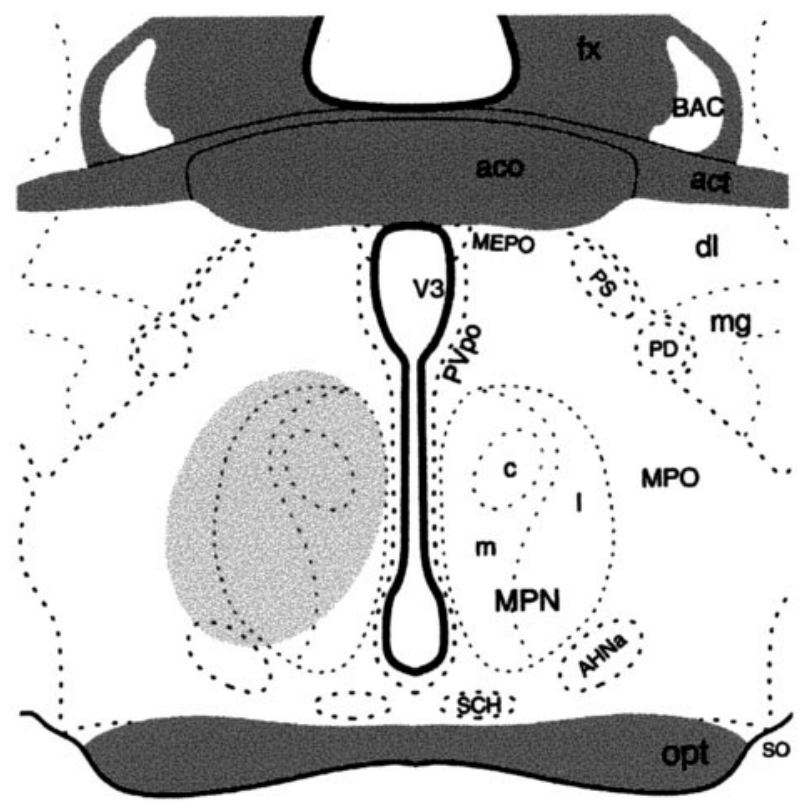

Figure 6. A schematic drawing of the medial preoptic (MP0) area through the anterior hypothalamus showing the extension of the FG injection site as indicated by the shaded portion. AHNa, Anterior hypothalamic nucleus, anterior part; act, anterior commissure, temporal limb; aco, anterior commissure; BAC, bed nucleus anterior commissure; $\mathrm{dl}$, bed nuclei stria terminalis, anterior division, dorsolateral nucleus; fx, fornix; mg, bed nuclei stria terminalis, anterior division, magnocellular nucleus; LPO, lateral preoptic area; MEPO, median preoptic nucleus; MPNI, medial preoptic nucleus, lateral part; MPNm, medial preoptic nucleus, medial part; MPNc, medial preoptic nucleus, central part; opt, optic chiasm; PD, posterodorsal preoptic nucleus; PS, parastrial nucleus; Pvpo, preoptic periventricular nucleus; $\mathrm{SCH}$, suprachiasmatic nucleus; $\mathrm{SO}$, supraoptic nucleus; V3, third ventricle. (Adapted from Swanson, 1998).

antibodies directed against $\mathrm{Y}_{1} \mathrm{R}$ and $\beta$-END. Most of the $\mathrm{Y}_{1} \mathrm{R}$ immunoreactive neurons were immunoreactive for $\beta$-END (95 $\pm 1.5 \%)$. Almost half of the $\beta$-END immunoreactive neurons were immunoreactive for $\mathrm{Y}_{1} \mathrm{R}(43 \pm 2.6 \%)$. No significant change of the percentage of colocalization was measured among the various steroid or peptide treatments $(p>0.05)$.

\section{Experiment 4: identification of ARH neurons projecting to MPN}

To label MPN efferents from the ARH, the retrograde tracer FG was microinjected into the MPN. Animals that were analyzed for this experiment had injection sites centered on the MPN (Fig. 6). Injection of FG into the MPN resulted in dense retrograde labeling throughout the rostrocaudal axis of the ARH. At all levels of the $A R H$, retrograde-labeled cells were distributed between $Y_{1} R$ and $\beta$-END immunoreactive cells. A population, $30 \pm 0.02 \%$ of the retrogradely labeled ARH cells, was $\mathrm{Y}_{1} \mathrm{R}$ and $\beta$-END immunoreactive (Fig. 7). In addition, $12 \pm 0.03 \%$ of the FG-labeled cells were $\mathrm{Y}_{1} \mathrm{R}$ immunoreactive, and another $28 \pm 0.05 \%$ were $\beta$-END immunoreactive.

\section{Experiment 5: specific $Y_{1} R$ activation inhibited lordosis}

To correlate receptive behavior with steroid-induced receptor trafficking, OVX rats were treated with $2 \mu \mathrm{g}$ of EB plus $500 \mu \mathrm{g}$ of progesterone every $4 \mathrm{~d}$ to induce sexual receptivity. In these steroid-primed females, injection of LPNY resulted in a significant overall decrease in lordosis compared with the vehicle controls $\left(F_{(1,44)}=79.08 ; p<0.05\right)$. A significant interaction was noted between treatment group (LPNY and vehicle control) and time $\left(15,30\right.$, and $45 \mathrm{~min}$ after injection) of LQ scores $\left(F_{(2,44)}=\right.$ 

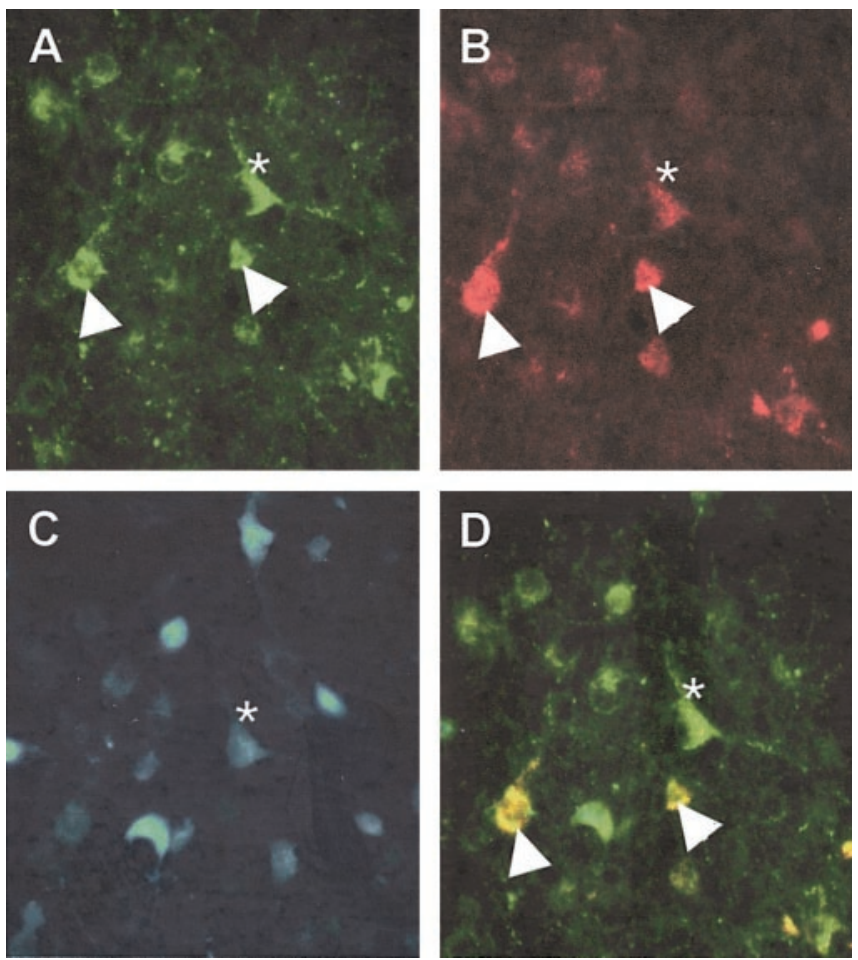

Figure 7. Photomicrograph of retrogradely labeled cells from the ARH after injection of FG into the MPN. The same field imaged to excite the FITC labeling $Y_{1} R(A)$, tetramethylrhodamine (TRITC) labeling $\beta$-END ( $B$ ), and FG-labeling efferent projections ( $C$ from the MPN. The images are combined in $D$. Doubly labeled $\beta$-END and $Y_{1} R$ immunoreactivity are yellow (arrowheads), and triple-labeled are white (asterisk).

7.68; $p<0.05)$. Post hoc analysis reveled that LPNY significantly decreased lordosis after 15,30 , and 45 min compared with vehicle-injected rats (Fig. $8 B)(p<0.05)$, indicating a correlation between neurochemical events demonstrating activation of the $\mathrm{Y}_{1} \mathrm{R}$ and MOR and lordosis behavior. There was neither a significant change in lordosis in the vehicle control across time nor when using NPY (Fig. 8A) $(p>0.05)$.

\section{Experiment 6: specific MOR blockade restores lordosis after} $\mathrm{Y}_{1} \mathrm{R}$ activation

To determine whether MOR activation was downstream of $Y_{1} R$ circuits, EB plus progesterone-primed females received intracerebroventricular microinjections of CTOP $(50 \mathrm{nmol} / 2 \mu \mathrm{l})$ or vehicle $(2 \mu \mathrm{laCSF})$, followed $10 \mathrm{~min}$ later with $\operatorname{LPNY}(10 \mathrm{nmol} / \mu \mathrm{l})$. There was a significant difference between CTOP-infused females and vehicle control $\left(F_{(1,32)}=48.15 ; p<0.05\right)$ and significant interaction between treatment group (CTOP or aCSF) and time $\left(15,30\right.$, or $45 \mathrm{~min}$ after injection) of LQ scores $\left(F_{(2,32)}=\right.$ 5.35; $p<0.05)$. Post hoc analysis revealed that the CTOP plus $\mathrm{Y}_{1} \mathrm{R}$ agonist-microinjected females showed a significantly greater LQ score at 15, 30, and 45 min when compared with aCSF plus $\mathrm{Y}_{1} \mathrm{R}$ (Fig. 8C) $(p<0.05)$. This indicates that CTOP administered before LPNY blocked the inhibitory effects of the $\mathrm{Y}_{1} \mathrm{R}$ agonist on lordosis.

\section{Discussion}

The major finding of these experiments is that activation of the $\mathrm{Y}_{1} \mathrm{R}$ in the mediobasal hypothalamus mediated by estrogen results in activation of MOR in the MPN that regulates sexual receptivity. Several lines of evidence support this finding. First, intracerebroventricular NPY or a selective $\mathrm{Y}_{1} \mathrm{R}$ agonist (LPNY)

\section{$A \stackrel{\substack{-a \\ \rightarrow-N P Y}}{\rightarrow-N P F}$}

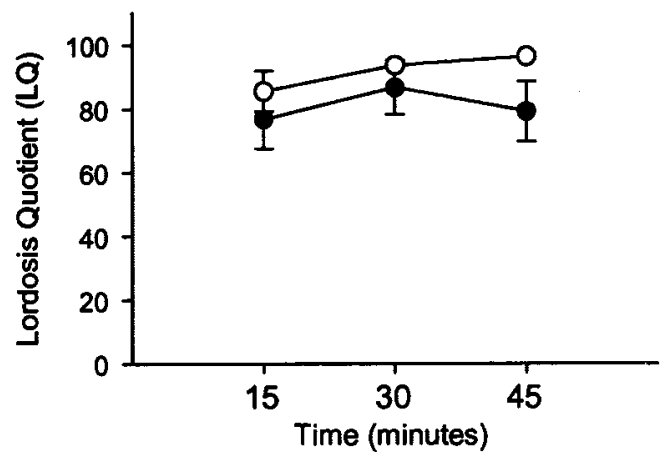

$B \stackrel{-O-a C S F}{-L P N Y}$

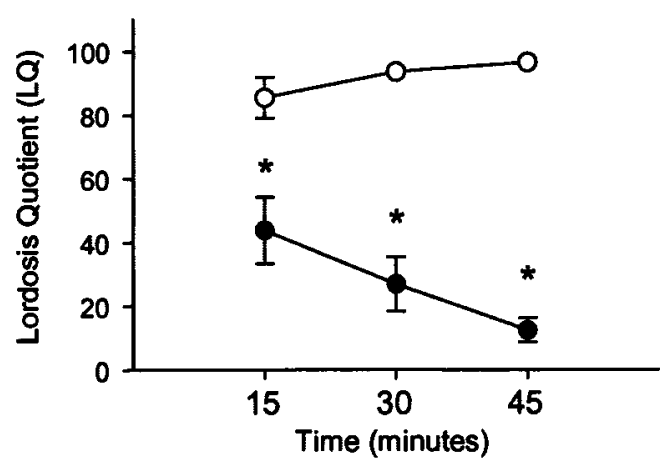

C $\rightarrow-$ CTOP+ LPNY

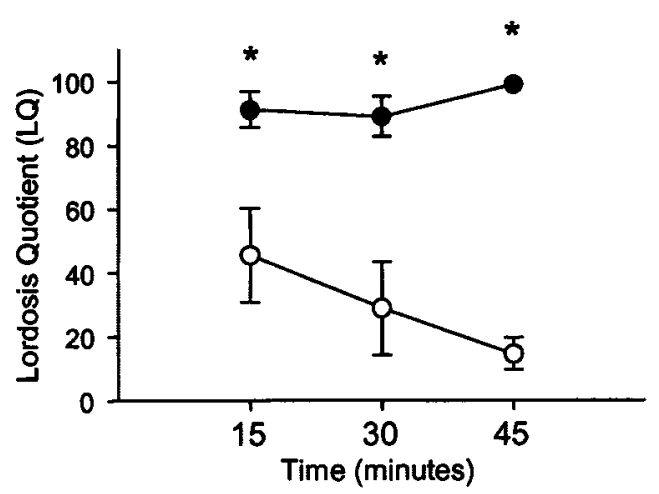

Figure 8. Sexual receptivity measured by $L Q$ in $2 \mu \mathrm{g}$ of $\mathrm{EB}$ plus $500 \mu \mathrm{g}$ of progesterone (P)-primed female rats infused with NPY or vehicle (aCSF) $(A)$; LPNY, a neuropeptide $Y-Y_{1}$ receptor agonist, or aCSF ( $B)$; or CTOP plus LPNY or aCSF + LPNY ( $C$ ) into the 3V (intracerebroventricular). $L Q$ was measured 15,30 , and 45 min after intracerebroventricular injection. There was significant decrease in lordosis in $Y_{1} R$ agonist-injected females compared with aCSF controls $(B)$, whereas CTOP + LPNY ( $C$ prevented the inhibition of lordosis at 15,30 , and 45 min after microinjection into the $3 \mathrm{~V}$. There was no significant difference in NPY-treated animals $(A)$. ${ }^{*} p<0.05$ versus aCSF.

into OVX rats induced the activation/internalization of MOR in the MPN, which was similar to the activation/internalization of MOR in the MPN after estrogen treatment (Eckersell et al., 1998; Sinchak and Micevych, 2001). Second, the estrogen-induced 
MOR internalization/activation was blocked by $\mathrm{CNNY}_{27-36}$, a selective antagonist of the $\mathrm{Y}_{1} \mathrm{R}$. Third, progesterone that blocked the estrogen-induced activation/internalization of MOR was reversed by NPY, indicating that the $\mathrm{Y}_{1} \mathrm{R}$ mediates progesterone actions that block estrogen-induced MOR internalization in the MPN. Fourth, internalization or noninternalization was correlated with behavior. EB plus progesterone facilitated lordosis, and LPNY, the $\mathrm{Y}_{1} \mathrm{R}$ agonist, inhibited lordosis. In addition, the MORspecific antagonist CTOP reversed the $\mathrm{Y}_{1} \mathrm{R}$-induced inhibition of lordosis. The present results combined with previous studies demonstrated that steroid activation of the $\mathrm{Y}_{1} \mathrm{R}$ and MOR in the hypothalamus inhibited lordosis (Sirinathsinghji, 1984; Clark et al., 1985; Gorzalka et al., 1997; Torii et al., 1999; Corp et al., 2001; Sinchak and Micevych, 2001). Finally, the present results provide evidence that these peptidergic circuits are not redundant but are organized in series to regulate behavior.

Although MOR activation in the MPN is correlated with inhibition of lordosis, the specific endogenous opioid peptide involved in the activation remains to be elucidated. Several types of endogenous opioid peptides activate the MOR, including $\beta$-END, the enkephalins, and the endomorphins (Borsodi and Toth, 1995). $\delta$-Opioid receptors preferentially bind enkephalin, but $\beta$-END and the endomorphins preferentially bind to MOR and inhibit EB or EB plus progesterone-induced lordosis (Sirinathsinghji, 1984; Sinchak and Micevych, 2001). Enkephalin and $\beta$-END expression have been shown to be regulated by estrogen (Wilcox and Roberts, 1985; Priest et al., 1995; Holland et al., 1998). Although endomorphins are the most MOR-selective endogenous opioid peptides (Zadina et al., 1999), to date, no studies indicate a steroid or NPY regulation of endormorphin cells. In contrast, estrogen-receptive $\beta$-END cell bodies are located in the ARH (Morrell et al., 1985), a region enriched in NPY and $Y_{1} R$ (Finley et al., 1981).

In the present study, we demonstrated that in female rats nearly all $\mathrm{Y}_{1} \mathrm{R}$ immunoreactive cells were $\beta$-END immunoreactive, a result that is consistent with previous findings in male rats (Fuxe et al., 1997). Approximately $43 \%$ of the $\beta$-END immunoreactivity were $\mathrm{Y}_{1} \mathrm{R}$ immunoreactive, and approximately onethird of the $\beta$-END/ $\mathrm{Y}_{1} \mathrm{R}$ immunoreactive neurons project to the MPN, demonstrating that a significant population of $\beta$-END/ $\mathrm{Y}_{1} \mathrm{R}$ immunoreactive neurons project to the MPN (Cheung et al., 1995). The present findings integrate reports that MOR inhibition of lordosis is mediated by the MPN (Sirinathsinghji, 1986; Torii and Kubo, 1994; Cheung et al., 1995; Sinchak and Micevych, 2001) and that NPY inhibition is mediated by the mediobasal hypothalamus (Clark et al., 1985).

In addition to localizing the $\mathrm{Y}_{1} \mathrm{R}$ in the $\mathrm{ARH}$, our results demonstrate that activation of a specific receptor is necessary for NPY inhibition of lordosis. In our hands, central injections of NPY did not inhibit lordosis; however, selective activation of the $\mathrm{Y}_{1} \mathrm{R}$ with LPNY inhibited lordosis. These results are congruent with the finding that $\mathrm{Y}_{1} \mathrm{R}$ mediates NPY actions on LH release (Kalra et al., 1992; Leupen et al., 1997; Li et al., 1999). The present results extend the observation that NPY inhibited lordosis in rats with a very robust estrogen-priming paradigm (100 $\mu \mathrm{g}$ of EB) (Clark et al., 1985). In our study, NPY did not inhibit lordosis in $2 \mu \mathrm{g}$ of EB plus $500 \mu \mathrm{g}$ of progesterone-treated rats; however, specific activation of $Y_{1} R$ did inhibit lordosis. We correlated the activation of this receptor (internalization) in the ARH with the inhibition of lordosis. One possibility for NPY for the discrepancy was that lordosis induced by EB is different from that induced by EB plus progesterone, as reported by Mani (2001).

Our results demonstrate the utility of using receptor internal- ization to map the activation of circuits in the CNS (Mantyh et al., 1995; Micevych et al., 1997). The phenomenon of receptor internalization is nearly ubiquitous. G-protein-coupled receptors, growth factor receptors, and, more recently, glutamate receptors, undergo internalization after agonist activation (Zaki et al., 2000; Mundell et al., 2001; Belcheva and Coscia, 2002). Although, in most cases, the internalization is related to desensitization and downregulation, it has become clear that internalization also may be involved in signaling (Vieira et al., 1996; Luttrell et al., 1997; Daaka et al., 1998; Ignatova et al., 1999). To our knowledge, we are the first to report that estrogen-induced MOR activation/ internalization in the MPN is dependent on $\mathrm{Y}_{1} \mathrm{R}$ activation/internalization in the ARH. Treatment of OVX rats with EB or NPY that induced $\mathrm{Y}_{1} \mathrm{R}$ internalization also induced MOR internalization, whereas EB-primed animals treated with a $\mathrm{Y}_{1} \mathrm{R}$ antagonist, $\mathrm{CNNY}_{27-36}$, blocked MOR internalization. Similarly, treatments that prevented EB-induced MOR internalization, such as progesterone, were overcome by treatment with NPY. Thus, MOR internalization, which is related to the EB-induced inhibition of lordosis, requires activation of $Y_{1} R$.

The site of estrogen activation remains to be elucidated. Estrogen has been shown to regulate the expression of $\beta$-END and its precursor mRNA (proopiomelanocortin) in the ARH (Barden et al., 1981; Wardlaw et al., 1982; Wilcox et al., 1986; Priest and Roberts, 2000). However, only a small population of $\beta$-END cells have estrogen receptors (Morrell et al., 1985; Jirikowski et al., 1986), suggesting that the observed estrogen effect is indirect, via transsynaptic mechanisms. To date, there is one preliminary report showing that a majority of NPY neurons have estrogen receptors (Cator et al., 2002). Estrogen receptor- $\alpha$ mRNA expression has been reported in the ARH (Shughrue et al., 1997; Osterlund et al., 1998), suggesting the possibility that estrogen directly regulates NPY synthesis and release. Our current results document $\mathrm{Y}_{1} \mathrm{R}$ on $\beta$-END neurons in the female rat ARH. When taken together with reports that NPY expression is regulated by estrogen (Crowley et al., 1985; Sahu et al., 1992; Baskin et al., 1995), our results suggest that gonadal steroid information is transduced through NPY neurons to $\beta$-END neurons that project to the MPN (Cheung et al., 1995; Cheung and Hammer, 1995), in which infusion of $\beta$-END antiserum augments estrogen-induced lordosis (Sirinathsinghji, 1986).

In summary, the present experiments support the hypothesis that estradiol and progesterone actions on NPY that sequentially activate $\mathrm{Y}_{1} \mathrm{R}$ and then MOR are part of the lordosis regulating circuitry that includes ARH $\beta$-END neurons that project to the MPN. These steroid-activated neuropeptide circuits are sequentially activated and functionally interrelated to modulate sexual receptivity and reproduction.

\section{References}

Abercrombie M (1946) Estimation of nuclear population from microtome sections. Anat Rec 94:239-247

Barden N, Merand Y, Rouleau D, Garon M, Dupont A (1981) Changes in the beta-endorphin content of discrete hypothalamic nuclei during the estrous cycle of the rat. Brain Res 204:441-445.

Baskin DG, Norwood BJ, Schwartz MW, Koerker DJ (1995) Estradiol inhibits the increase of hypothalamic neuropeptide Y messenger ribonucleic acid expression induced by weight loss in ovariectomized rats. Endocrinology 136:5547-5554.

Belcheva MM, Coscia CJ (2002) Diversity of G protein-coupled receptor signaling pathways to ERK/MAP kinase. Neurosignals 11:34-44.

Besecke LM, Wolfe AM, Pierce ME, Takahashi JS, Levine JE (1994) Neuropeptide $\mathrm{Y}$ stimulates luteinizing hormone-releasing hormone release from superfused hypothalamic GT1-7 cells. Endocrinology 135:1621-1627. 
Borsodi A, Toth G (1995) Characterization of opioid receptor types and subtypes with new ligands. Ann NY Acad Sci 757:339-352.

Broberger C, Landry M, Wong H, Walsh JN, Hokfelt T (1997) Subtypes Y1 and $\mathrm{Y} 2$ of the neuropeptide $\mathrm{Y}$ receptor are respectively expressed in proopiomelanocortin- and neuropeptide-Y-containing neurons of the rat hypothalamic arcuate nucleus. Neuroendocrinology 66:393-408.

Cator AD, DeJoseph MR, Urban JH (2002) Distribution of NPY receptors and estrogen receptors in rat hypothalamus. Soc Neurosci Abstr 73.4.

Cheung S, Hammer Jr RP (1995) Gonadal steroid hormone regulation of proopiomelanocortin gene expression in arcuate neurons that innervate the medial preoptic area of the rat. Neuroendocrinology 62:283-292.

Cheung S, Salinas J, Hammer Jr RP (1995) Gonadal steroid hormonedependence of beta-endorphin-like immunoreactivity in the medial preoptic area of the rat. Brain Res 675:83-88.

Clark JT, Kalra PS, Kalra SP (1985) Neuropeptide Y stimulates feeding but inhibits sexual behavior in rats. Endocrinology 117:2435-2442.

Corp ES, Greco B, Powers JB, Bivens CL, Wade GN (2001) Neuropeptide Y inhibits estrous behavior and stimulates feeding via separate receptors in Syrian hamsters. Am J Physiol Regul Integr Comp Physiol 280:R1061-R1068.

Crowley WR, Tessel RE, O’Donohue TL, Adler BA, Kalra SP (1985) Effects of ovarian hormones on the concentrations of immunoreactive neuropeptide $\mathrm{Y}$ in discrete brain regions of the female rat: correlation with serum luteinizing hormone (LH) and median eminence LH-releasing hormone. Endocrinology 117:1151-1155.

Daaka Y, Luttrell LM, Ahn S, Della Rocca GJ, Ferguson SS, Caron MG, Lefkowitz RJ (1998) Essential role for G protein-coupled receptor endocytosis in the activation of mitogen-activated protein kinase. J Biol Chem 273:685-688

Dournaud P, Boudin H, Schonbrunn A, Tannenbaum GS, Beaudet A (1998) Interrelationships between somatostatin sst2A receptors and somatostatin-containing axons in rat brain: evidence for regulation of cell surface receptors by endogenous somatostatin. J Neurosci 18:1056-1071.

Eckersell CB, Popper P, Micevych PE (1998) Estrogen-induced alteration of $\mu$-opioid receptor immunoreactivity in the medial preoptic nucleus and medial amygdala. J Neurosci 18:3967-3976.

Finley JC, Lindstrom P, Petrusz P (1981) Immunocytochemical localization of beta-endorphin-containing neurons in the rat brain. Neuroendocrinology 33:28-42.

Fuxe K, Tinner B, Caberlotto L, Bunnemann B, Agnati LF (1997) NPY Y1 receptor like immunoreactivity exists in a subpopulation of betaendorphin immunoreactive nerve cells in the arcuate nucleus: a double immunolabelling analysis in the rat. Neurosci Lett 225:49-52.

Fuxe R, Agnati L, Zoli M, Cintra A, Härfstrand A, von Euler G, Grimaldi R, Kalia M, Eneroth P (1998) The opioid peptide systems: their organization and role in volume transmission and neuroendocrine regulation. In: Regulatory roles of opioid peptides (Illes P, Farsang C, eds), pp 33-68. New York: Weinheim.

Gorzalka BB, Heddema GM, Lester GL, Hanson LA (1997) Beta-endorphin inhibits and facilitates lordosis behaviour in rats depending on ventricular site of administration. Neuropeptides 31:517-521.

Holland KL, Norby LA, Micevych PE (1998) Peripubertal ontogeny and estrogen stimulation of cholecystokinin and preproenkephalin mRNA in the rat hypothalamus and limbic system. J Comp Neurol 392:48-57.

Ignatova EG, Belcheva MM, Bohn LM, Neuman MC, Coscia CJ (1999) Requirement of receptor internalization for opioid stimulation of mitogenactivated protein kinase: biochemical and immunofluorescence confocal microscopic evidence. J Neurosci 19:56-63.

Jain MR, Pu S, Kalra PS, Kalra SP (1999) Evidence that stimulation of two modalities of pituitary luteinizing hormone release in ovarian steroidprimed ovariectomized rats may involve neuropeptide Y Y1 and Y4 receptors. Endocrinology 140:5171-5177.

Jirikowski GF, Merchenthaler I, Rieger GE, Stumpf WE (1986) Estradiol target sites immunoreactive for beta-endorphin in the arcuate nucleus of rat and mouse hypothalamus. Neurosci Lett 65:121-126.

Kalra SP, Fuentes M, Fournier A, Parker SL, Crowley WR (1992) Involvement of the Y-1 receptor subtype in the regulation of luteinizing hormone secretion by neuropeptide $\mathrm{Y}$ in rats. Endocrinology 130:3323-3330.

Khachaturian H, Alessi NE, Munfakh N, Watson SJ (1983) Ontogeny of opioid and related peptides in the rat cns and pituitary: an immunocytochemical study. Life Sci 33 [Suppl 1]:61-64.

Leupen SM, Besecke LM, Levine JE (1997) Neuropeptide Y Y1-receptor stimulation is required for physiological amplification of preovulatory luteinizing hormone surges. Endocrinology 138:2735-2739.

Li C, Chen P, Smith MS (1999) Morphological evidence for direct interaction between arcuate nucleus neuropeptide Y (NPY) neurons and gonadotropin-releasing hormone neurons and the possible involvement of NPY Y1 receptors. Endocrinology 140:5382-5390.

Luttrell LM, Daaka Y, Della Rocca GJ, Lefkowitz RJ (1997) G proteincoupled receptors mediate two functionally distinct pathways of tyrosine phosphorylation in rat 1a fibroblasts. Shc phosphorylation and receptor endocytosis correlate with activation of Erk kinases. J Biol Chem 272:31648-31656.

Mani S (2001) Ligand-independent activation of progestin receptors in sexual receptivity. Horm Behav 40:183-190.

Mantyh PW, Allen CJ, Ghilardi JR, Rogers SD, Mantyh CR, Liu H, Basbaum AI, Vigna SR, Maggio JE (1995) Rapid endocytosis of a G proteincoupled receptor: substance $P$ evoked internalization of its receptor in the rat striatum in vivo. Proc Natl Acad Sci USA 92:2622-2626.

Micevych PE, Elde RP (1982) Neurons containing alpha-melanocyte stimulating hormone and beta-endorphin immunoreactivity in the cat hypothalamus. Peptides 3:655-662.

Micevych PE, Eckersell CB, Brecha N, Holland KL (1997) Estrogen modulation of opioid and cholecystokinin systems in the limbic-hypothalamic circuit. Brain Res Bull 44:335-343.

Migita K, Loewy AD, Ramabhadran TV, Krause JE, Waters SM (2001) Immunohistochemical localization of the neuropeptide Y Y 1 receptor in rat central nervous system. Brain Res 889:23-37.

Mikkelsen JD, Larsen PJ (1992) A high concentration of NPY (Y1)-receptor mRNA-expressing cells in the rat arcuate nucleus. Neurosci Lett 148:195-198.

Mills RH, Sohn RK, Micevych PE (2001) Neuropeptide Y facilitates muopioid receptor activation in the medial preoptic nucleus in female rats Horm Behav 39:339.

Morrell JI, McGinty JF, Pfaff DW (1985) A subset of beta-endorphin- or dynorphin-containing neurons in the medial basal hypothalamus accumulates estradiol. Neuroendocrinology 41:417-426.

Mundell SJ, Matharu AL, Pula G, Roberts PJ, Kelly E (2001) Agonistinduced internalization of the metabotropic glutamate receptor $1 \mathrm{a}$ is arrestin- and dynamin-dependent. J Neurochem 78:546-551.

Osterlund M, Kuiper GG, Gustafsson JA, Hurd YL (1998) Differential distribution and regulation of estrogen receptor-alpha and -beta mRNA within the female rat brain. Brain Res Mol Brain Res 54:175-180.

Parker SL, Carroll BL, Kalra SP, St. Pierre S, Fournier A, Crowley WR (1996) Neuropeptide Y Y2 receptors in hypothalamic neuroendocrine areas are up-regulated by estradiol and decreased by progesterone cotreatment in the ovariectomized rat. Endocrinology 137:2896-2900.

Petraglia F, Penalva A, Locatelli V, Cocchi D, Panerai AE, Genazzani AR, Muller EE (1982) Effect of gonadectomy and gonadal steroid replacement on pituitary and plasma beta-endorphin levels in the rat. Endocrinology 111:1224-1229.

Pickel VM, Beck-Sickinger AG, Chan J, Weiland HA (1998) Y1 receptors in the nucleus accumbens: ultrastructural localization and association with neuropeptide Y. J Neurosci Res 52:54-68.

Priest CA, Roberts JL (2000) Estrogen and tamoxifen differentially regulate beta-endorphin and cFos expression and neuronal colocalization in the arcuate nucleus of the rat. Neuroendocrinology 72:293-305.

Priest CA, Eckersell CB, Micevych PE (1995) Estrogen regulates preproenkephalin-A mRNA levels in the rat ventromedial nucleus: temporal and cellular aspects. Brain Res Mol Brain Res 28:251-262.

Sahu A, Phelps CP, White JD, Crowley WR, Kalra SP, Kalra PS (1992) Steroidal regulation of hypothalamic neuropeptide $\mathrm{Y}$ release and gene expression. Endocrinology 130:3331-3336.

Sar M, Sahu A, Crowley WR, Kalra SP (1990) Localization of neuropeptide-Y immunoreactivity in estradiol-concentrating cells in the hypothalamus. Endocrinology 127:2752-2756.

Shughrue PJ, Lane MV, Merchenthaler I (1997) Comparative distribution of estrogen receptor-alpha and -beta mRNA in the rat central nervous system. J Comp Neurol 388:507-525.

Sinchak K, Micevych P (2003) Visualizing activation of opioid circuits by internalization of $\mathrm{G}$ protein-coupled receptors. Mol Neurobiol 27:197-222.

Sinchak K, Micevych PE (2001) Progesterone blockade of estrogen activa- 
tion of mu-opioid receptors regulates reproductive behavior. J Neurosci 21:5723-5729.

Sirinathsinghji DJ (1984) Modulation of lordosis behavior of female rats by naloxone, beta-endorphin and its antiserum in the mesencephalic central gray: possible mediation via GnRH. Neuroendocrinology 39:222-230.

Sirinathsinghji DJ (1986) Regulation of lordosis behaviour in the female rat by corticotropin- releasing factor, beta-endorphin/corticotropin and luteinizing hormone- releasing hormone neuronal systems in the medial preoptic area. Brain Res 375:49-56.

Sirinathsinghji DJ, Whittington PE, Audsley A, Fraser HM (1983) betaEndorphin regulates lordosis in female rats by modulating $\mathrm{LH}-\mathrm{RH}$ release. Nature 301:62-64.

Swanson LW (1998) Brain maps: structure of the rat brain. Amsterdam: Elsevier.

Torii M, Kubo K (1994) The effects of intraventricular injection of betaendorphin on initial estrogen action to induce lordosis behavior. Physiol Behav 55:157-162.

Torii M, Kubo K, Sasaki T (1999) Facilitatory and inhibitory effects of betaendorphin on lordosis in female rats: relation to time of administration. Horm Behav 35:271-278.

Vieira AV, Lamaze C, Schmid SL (1996) Control of EGF receptor signaling by clathrin-mediated endocytosis. Science 274:2086-2089.

von Zastrow M, Link R, Daunt D, Barsh G, Kobilka B (1993) Subtype- specific differences in the intracellular sorting of $G$ protein- coupled receptors. J Biol Chem 268:763-766.

Wardlaw SL, Thoron L, Frantz AG (1982) Effects of sex steroids on brain beta-endorphin. Brain Res 245:327-331.

Wiesner JB, Moss RL (1984) Beta-endorphin suppression of lordosis behavior in female rats; lack of effect of peripherally-administered naloxone. Life Sci 34:1455-1462.

Wilcox JN, Roberts JL (1985) Estrogen decreases rat hypothalamic proopiomelanocortin messenger ribonucleic acid levels. Endocrinology 117:2392-2396.

Wilcox JN, Roberts JL, Chronwall BM, Bishop JF, O’Donohue T (1986) Localization of proopiomelanocortin mRNA in functional subsets of neurons defined by their axonal projections. J Neurosci Res 16:89-96.

Xu M, Urban JH, Hill JW, Levine JE (2000) Regulation of hypothalamic neuropeptide Y Y1 receptor gene expression during the estrous cycle: role of progesterone receptors. Endocrinology 141:3319-3327.

Zadina JE, Martin-Schild S, Gerall AA, Kastin AJ, Hackler L, Ge LJ, Zhang X (1999) Endomorphins: novel endogenous mu-opiate receptor agonists in regions of high mu-opiate receptor density. Ann NY Acad Sci 897:136-144.

Zaki PA, Keith Jr DE, Brine GA, Carroll FI, Evans CJ (2000) Ligand-induced changes in surface mu-opioid receptor number: relationship to $\mathrm{G}$ protein activation? J Pharmacol Exp Ther 292:1127-1134. 